\title{
Appel à contribution / Call for Papers
}

\author{
Numéro spécial «Traduire et lire Le Deuxième Sexe à l'échelle globale» \\ Rédactrices invitées : Sylvie Chaperon et Marine Rouch \\ Date limite : 1 mars 2020
}

Depuis sa parution en 1949, Le Deuxième Sexe a été traduit dans des dizaines de langues, à chaque fois dans un contexte éditorial, intellectuel et féministe particulier. Chaque traduction a donné lieu à des adaptations et à des transformations différentes, lesquelles ont ensuite connu une réception critique ainsi qu' une appropriation par ses lecteur.trice.s ordinaires. Pour ce numéro spécial de la revue Simone de Beauvoir Studies ( $S d B S$ 31.2, octobre 2020), nous souhaitons recevoir des articles complets de 7000-8000 mots (en anglais ou en français) analysant la chaîne des choix complexes faits par les éditeur.trice.s et les traducteur.trice.s, puis leurs conséquences sur les réceptions immédiates et les postérités de l'œuvre en divers contextes. Les aires culturelles encore peu examinées par les études beauvoiriennes seront privilégiées: l'Europe du Nord et de l'Est, l'Afrique, l' Amérique latine et l' Asie.

\section{Special Issue "Reading and Translating The Second Sex Globally" Guest Editors: Sylvie Chaperon and Marine Rouch \\ Deadline: March 1, 2020}

Since its publication in France in 1949, The Second Sex has been translated into dozens of languages, and each time in a particular editorial, intellectual, and feminist context. Each translation has given rise to different adaptations and transformations of the text, which are later subject to critical receptions and appropriations by ordinary readers. For this special issue of Simone de Beauvoir Studies ( $S d B S$ 31.2, October 2020), we seek completed articles of 7000-8000 words (in English or in French) that analyze the chains of complex choices implemented by editors and translators, as well as the consequences of these choices on the immediate reception and legacy of the work in diverse contexts. We especially invite submissions on cultural areas that are underexplored in Beauvoir studies: Northern and Eastern Europe, Africa, Latin America, and Asia. 